Review

\title{
Epigallocatechin Gallate Modulates Muscle Homeostasis in Type 2 Diabetes and Obesity by Targeting Energetic and Redox Pathways: A Narrative Review
}

\author{
Ester Casanova $^{1, *}+\boldsymbol{t}^{\mathbb{D}}$, Josepa Salvadó ${ }^{1}\left(\mathbb{D}\right.$, Anna Crescenti ${ }^{2}$ and Albert Gibert-Ramos ${ }^{1, *,+(\mathbb{D})}$ \\ 1 Nutrigenomics Research Group, Department of Biochemistry and Biotechnology, Universitat Rovira i \\ Virgili (URV), Campus Sescelades, 43007 Tarragona, Spain; mariajosepa.salvado@urv.cat \\ 2 Technological Unit of Nutrition and Health, EURECAT-Technology Centre of Catalonia, Avinguda \\ Universitat 1, 43204 Reus, Spain; anna.crescenti@eurecat.org \\ * Correspondence: ester.casanova@urv.cat (E.C.); albert.gibert@urv.cat (A.G.-R.); \\ Tel.: +34-977-559-567 (E.C.); Fax: +34-977-558-232 (A.G.-R.) \\ + These authors contributed equally to this work.
}

Received: 16 January 2019; Accepted: 22 January 2019; Published: 27 January 2019

\begin{abstract}
Obesity is associated with the hypertrophy and hyperplasia of adipose tissue, affecting the healthy secretion profile of pro- and anti-inflammatory adipokines. Increased influx of fatty acids and inflammatory adipokines from adipose tissue can induce muscle oxidative stress and inflammation and negatively regulate myocyte metabolism. Muscle has emerged as an important mediator of homeostatic control through the consumption of energy substrates, as well as governing systemic signaling networks. In muscle, obesity is related to decreased glucose uptake, deregulation of lipid metabolism, and mitochondrial dysfunction. This review focuses on the effect of epigallocatechin-gallate (EGCG) on oxidative stress and inflammation, linked to the metabolic dysfunction of skeletal muscle in obesity and their underlying mechanisms. EGCG works by increasing the expression of antioxidant enzymes, by reversing the increase of reactive oxygen species (ROS) production in skeletal muscle and regulating mitochondria-involved autophagy. Moreover, EGCG increases muscle lipid oxidation and stimulates glucose uptake in insulin-resistant skeletal muscle. EGCG acts by modulating cell signaling including the NF-KB, AMP-activated protein kinase (AMPK), and mitogen-activated protein kinase (MAPK) signaling pathways, and through epigenetic mechanisms such as DNA methylation and histone acetylation.
\end{abstract}

Keywords: epigallocatechin gallate; obesity; muscle; oxidative stress; cell signaling

\section{Structure, Bioavailability and Metabolism of Epigallocatechin Gallate}

Epigallocatechin gallate (EGCG) is a major constituent of green tea $(7380 \mathrm{mg}$ per $100 \mathrm{~g}$ of dried leaves). Smaller amounts of EGCG are found in apple skin, plums, onions, hazelnuts, pecans and carob powder (at $109 \mathrm{mg}$ per $100 \mathrm{~g}$ ) [1]. Green tea, from the Camellia sinensis L., contains very high levels of flavan-3-ols monomers, also known as catechins, and its main components are (-)-epicatechin (EC), (-)-epigallocatechin (EGC), (-)-epicatechin gallate (ECG), and (-)-epigallocatechin gallate (EGCG). Green tea leaves are steamed to reduce oxidation, however, during the production of black tea, the levels of flavan-3-ols drop. The reason behind is that tea leaves are processed in a specific way that includes fermentation, which converts these flavan-3-ols in theaflavins and thearubigins [2]. 


\subsection{Molecular Structure}

The structure of EGCG consists of four rings resulting from the esterification of EGC with gallic acid: the $\mathrm{A}$ and $\mathrm{C}$ rings constitute the benzopyran ring with a pyrogallol moiety at position 2 , the $\mathrm{B}$ ring, with a gallate moiety at position 3 , and the $\mathrm{D}$ ring (Figure 1 ). The presence of this ester carbon makes EGCG highly susceptible to nucleophilic attack [3]. The B and D rings of EGCG have vicinal 3', $4^{\prime}, 5^{\prime}$ and $3^{\prime \prime}, 4^{\prime \prime}$ and $5^{\prime \prime}$-trihydroxy groups respectively, which give EGCG its anti-oxidative potential [3]. These ortho-dihydroxy pairings found in rings B and D account for EGCG's potent divalent metal chelating capacity [4]. EGCG has been found to be a more efficient radical scavenger than its structural analogues EGC, EC, and ECG, which all have fewer hydroxyl groups [4]. The EGCG molecule is less stable in neutral and alkaline media because the hydroxyl groups on the phenyl ring are attacked by the basic medium, leading to the formation of a more active phenoxide anion. This instability results in low bioavailability [3].<smiles>Cc1c(O)cc(O)cc1O[C@@H](c1c[R](O)c(O)c(O)c1)[C@H](C)OC(=O)c1cc(O)c(O)c(O)c1</smiles>

(-)-Epigallocatechin-3-gallate

Figure 1. Chemical structure of (-)-Epigallocatechin-3-gallate. The four rings resulting from the esterification of epigallocatechin (EGC) with gallic acid are indicated by letters (A, B, C and D) and each carbon from each ring is indicated by numbers (1-8).

\subsection{Bioavailability and Metabolism}

Many studies have shown a low systemic bioavailability of EGCG when it is taken orally. In an acute feeding study, healthy human subjects consumed $500 \mathrm{~mL}$ of green tea containing $648 \mu \mathrm{mol}$ of flavan-3-ols, after which plasma and urine were collected over a 24-h period and analyzed by HPLC-MS [5]. The plasma contained a total of 10 metabolites in the form of $O$-methylated, sulfated, and glucuronide conjugates of EC and EGC, along with the native green tea flavan-3-ols EGCG and ECG [5]. The peak plasma concentration (Cmax) of unmetabolized EGCG was $55 \mathrm{nM}$ and the time to reach Cmax (Tmax) was $1.6 \mathrm{~h}$. Both the Tmax and the observed transformations are indicative of absorption in the small intestine [6]. The appearance of unmetabolized EGCG and ECG in plasma is unusual in dietary flavonoids and might be a consequence of the galloyl moiety inhibiting phase II metabolism $[7,8]$.

While catechins are usually glucuronidated or sulfated in human plasma, EGCG can be found in free form and in high proportions (77-90\%) [9-12]. Nevertheless, the fact remains that EGCG is poorly absorbed when administered orally due to its high solubility, resulting in low membrane permeability in human studies [4]. Moreover, EGCG is stable during gastric digestion at a low $\mathrm{pH}$, but very unstable under duodenal conditions, in a more alkaline medium, which leads to low bioavailability.

The plasma levels of EGCG after intragastric administration of decaffeinated green tea to rats was found to be $0.1 \%$ [13]. Ullmann and colleagues reported that after the administration of $1600 \mathrm{mg}$ EGCG to healthy volunteers, the Cmax was $3392 \mathrm{ng} / \mathrm{mL}$ [12]. Other human studies on the plasma kinetics of 
EGCG and its conjugated metabolites indicated that the total mean of EGCG area under the plasma concentration time curve between 0 -h to infinity (AUC (0-N)) ranged from 442 to 10,368 $\mathrm{ng} \cdot \mathrm{h} / \mathrm{mL}$, and the mean terminal elimination half-life $(\mathrm{t} 1 / 2 \mathrm{z})$ was from 1.9 to $4.6 \mathrm{~h}$ when purified and isolated EGCG was supplemented to healthy individuals [12]. In addition, another study examined the plasma kinetics of purified EGCG after administrations of $800 \mathrm{mg}$ once per day and $400 \mathrm{mg}$ twice per day for 4 weeks [9]. A peak in the serum levels of EGCG was observed after it had been administered at 400 and $800 \mathrm{mg}$ [9]. An unexpected high amount of bound EGCG was found when the affinity of EGCG for human serum albumin was tested in physiological conditions. These results imply that almost all EGCG is transported in the blood bound to albumin, and explains the wide tissue distribution and chemical stability of EGCG in vivo [14]. EGCG kinetics have also been studied in rat and mouse models. Male Sprague Dawley rats that were given $0.6 \%$ green tea in their drinking water for 14 days had an EGCG concentration in the large intestine of $487.8 \pm 121.5 \mathrm{ng} / \mathrm{g}$, while its concentration in the bladder was approximately of $201.4 \pm 154 \mathrm{ng} / \mathrm{g}$ EGCG [15]. A few studies have shown that EGCG does indeed cross the blood-brain barrier $[16,17]$. In particular, male and female mice administered orally with $200 \mu \mathrm{L}$ of $0.05 \%$ EGCG solution containing $3.7 \mathrm{MBq}\left[{ }^{3} \mathrm{H}\right] \mathrm{EGCG}$ displayed $0.32 \%$ and $0.33 \%$, respectively, of total radioactivity in the brain $24 \mathrm{~h}$ after uptake, which was comparable with most other organs [17]. Kohri et al. showed that after an oral administration of radioactive EGCG, its concentration in blood starts to increase after $8 \mathrm{~h}$, shows a peak at $24 \mathrm{~h}$, and then starts to decrease. In their study, they also show that major urinary excretion happened during the increase and peak periods, and that at $72 \mathrm{~h}$ its excretion was $32.1 \%$ of the oral dose, while its excretion in the feces during the following $72 \mathrm{~h}$ was $35.2 \%$ of the dose [18]. Kohri and colleagues also studied the metabolic fate of EGCG in rats supplemented with antibiotics and $\left[4-{ }^{3} \mathrm{H}\right] \mathrm{EGCG}$, and found that the excretion levels were lower than in normal rats, and so, concluded that the radioactivity observed in the blood and urine came from EGCG degradation by the microbiota. Additionally, the authors report that a particular metabolite in the normal rats was purified and identified as 5-(5'-hydroxyphenyl)- $\gamma$-valerolactone $3^{\prime}-O-\beta$-glucuronide (M-2), while in feces, EGC (40.8\% of the fecal radioactivity) and 5-( $3^{\prime}, 5^{\prime}$-dihydroxyphenyl)- $\gamma$-valerolactone (M-1, $16.8 \%$ ) were detected [18]. They propose that M-1 was absorbed in the body after EGCG was degraded by intestinal bacteria, yielding M-1 with EGC as an intermediate. Additionally, M- 2 could have been formed from M-1 in the intestinal mucosa and/or liver, then entered the systemic circulation, and finally excreted in the urine [18].

Urine excreted 0 to $24 \mathrm{~h}$ after green tea consumption, contained a profile of flavan-3-ol conjugates similar to the plasma; however, ECG and EGCG were undetectable [18]. These outcomes indicate that the intact flavan-3-ols, ECG and EGCG do not undergo extensive metabolic modifications. Several researchers have observed that it is not possible to detect EGCG in urine, despite its presence in plasma $[9,19,20]$, which is difficult to explain. It could be that the kidneys are unable to absorb EGCG from the plasma; however, if this is the case, there must be other mechanisms that produce its rapid decline after Cmax is reached [21]. Auger et al. [22] supplemented patients with an ileostomy with pure EGCG from green tea and analyzed the ileal fluid and urine over a period of $24 \mathrm{~h}$. They did not find EGC or its metabolites in urine, thus establishing that degalloylation did not occur endogenously [21]. It has been hypothesized in animal studies that EGCG may be cleared from the plasma in the liver and returned to the small intestine through the bile [23,24]. Although this enterohepatic recirculation is not yet proven in humans, it might be possible that this EGCG from the bile is degallated by the gut microbiota, and then, if no more degradation happens, it is excreted in urine as EC and EGC metabolites [6].

Most of the consumed flavan-3-ols after green tea ingestion reach the large intestine where they are modified by the microbiota. These successive modifications result in their transformation to C-6-C-5 phenylvalerolactones and phenylvaleric acids, followed by their conversion into C-6-C-1 phenolic and aromatic acids, which are absorbed by the colon, enter the bloodstream, and are excreted in urine. The total amount that finally exits the body through urine is approximately a third of the ingested flavan-3-ols [21]. Moreover, it is believed that these transformations that occur in the 
colon might have important bioactive effects, and that these effects might vary between individuals because of differences in the microbiota composition. Even so, further studies are needed to make such assumptions [25].

It has been found, comparing two acute green tea feeding studies, one with volunteers subjected to an ileostomy [26] and the other with healthy individuals [5], that there were almost no differences in the plasmatic flavan-3-ol pharmacokinetics. These results indicated that flavan-3-ol monomers are principally absorbed in the upper part of the gastrointestinal tract [6]. Even so, it was also reported in the study with human subjects with an ileostomy that the ileal fluid contained $70 \%$ of the initially supplemented green tea flavan-3-ols [26]. Therefore, it can be stated that, in healthy subjects, the major part of favan-3-ols consumed will pass from the small to large intestines [6].

\section{Muscle in Obesity: The Problem of Inflammation}

Obesity is a term defined by the World Health Organization (WHO) that involves an abnormal or excessive amount of body fat accumulation that presents a risk to health [27]. Nowadays, obesity is becoming a global public health issue because affected individuals are at a major risk of developing a big range of comorbidities such as cardiovascular disease, type 2 diabetes (T2D) and respiratory disorders, among others [28,29].

Recent insights in obesity indicate that the adipose tissue exerts an inflammatory influence on the body. The metabolic effects of inflammation include insulin insensitivity, hyperlipidemia, muscle protein loss and oxidant stress [30]. Activation of the immune system increases the production of oxidant molecules. Moreover, oxidants could take part in the inflammatory response activating the nuclear factor kappa-B (NF- $\mathrm{kB}$ ) which is linked to many of the genes related to the inflammatory response [31]. White adipose tissue derivatives, either fatty acids (FA) or inflammatory cytokines, in obesity have many adverse and synergistic effects on the skeletal metabolism [32]. High levels of interleukin-6 (IL-6), an inflammatory cytokine, are associated with insulin resistance (IR) and T2D [33-35] likely due to greater white adipose tissue IL-6 secretion [36,37].

In obesity and T2D subjects, the IL-6 signaling pathway in muscle cells has an abnormal function because there is a reduction in the expression of IL-6 receptor and also an abnormal STAT3/suppressor of cytokine signaling 3 (SOCS3) in adipose tissue $[35,38]$. SOCS3 is involved in the inhibition of leptin and insulin signaling, and has been found to be elevated in the skeletal muscle of mice fed with a high fat diet [39] and in insulin resistant states [40]. Overexpression of SOCS3 impairs leptin-stimulated AMPK activation, reduces tyrosine phosphorylation of IRS-1, PI-3-kinase activity, and AKT phosphorylation [39]. Thus, the reduction of SOCS3 expression in most cases could improve leptin and insulin resistance [41].

In addition, the lipid excess observed in obesity damages the muscle, causing cellular dysfunctions. Indeed, lipid excess in skeletal muscle activates endoplasmic reticulum (ER) stress and, consequently, the accumulation of unfolded or misfolded proteins in the ER lumen. Furthermore, it has been shown that the muscles of obese insulin-resistant individuals contain almost $30 \%$ less mitochondria than normal individuals [42], which suggests that muscles have less capacity to oxidize fatty acids, and thus contribute to insulin resistance.

Currently, there are many studies focusing on the treatment of the systemic inflammation induced by obesity and T2D, and particularly, through the use of natural bioactive compounds $[43,44]$, which are usually harmless and more secure than synthetic drugs [45]. Moreover, targeting obesity-induced inflammation would be useful for the treatment of obesity and related diseases, since this state is linked to many illnesses or problematics, such as an overall activation of the immune system [46], cancer [47] or metabolic diseases [48].

\section{EGCG on Energy Metabolism: Animal Models and Human Studies}

In recent years, the interest in the health benefits of dietary components for preventing obesity and T2D has increased [49]. Specifically, polyphenol compounds such as a green tea extract rich in 
EGCG exert anti-obesogenic properties [50,51]. Preclinical studies on animals and some studies on humans have confirmed the beneficial effects of EGCG [29] on obesity-related parameters including decreased body weight [52-54], decreased adipose mass [52], reduction of food intake [55], decreased total lipids, cholesterol and triglyceride in the liver and plasma, and an improvement in glucose homeostasis $[52,53,56]$. Various mechanisms have been proposed to produce these responses, including suppression of dietary fat absorption [52,57,58], enhancement of fat oxidation in adipose tissue and skeletal muscle [53,59], increase of glucose utilization $[52,60,61]$, and decrease of de novo lipogenesis [59,62,63].

Moreover, data also provide evidence that green tea extracts have beneficial effects improving body composition and weight $[53,64,65]$, reducing body fat $[53,60,61]$, improving glucose and lipid metabolism $[53,61,65]$, and protecting against ER stress, oxidative stress and protein degradation induced by high fat diet in skeletal muscle [66].

Treatment of C57b1/6J mice with $0.32 \%$ dietary EGCG for 16 weeks has been shown to reduce body weight gain and markers of T2D [52] induced by a high fat diet. In obese KK-ay mice, EGCG reduces ROS content, decreases glucose levels and increases glucose tolerance in animals [67]. Some of these effects are mediated by epigenetic mechanisms because, one of the mechanisms of EGCG appears to be the direct inhibition of DNA methyltransferases (DNMT) $[68,69]$.

Laboratory studies with animal models have generally demonstrated that green tea and EGCG play a role in the prevention of obesity and have beneficial effects on glucose homeostasis, oxidative stress and lipid metabolism [49]. However, the effects on humans have been less studied. Epidemiological studies have suggested some of the possible effects of EGCG on humans, but there are few controlled intervention studies and many of these have different methodological designs. Therefore, more studies are needed to elucidate the action mechanisms [70]. A few studies have been carried out on humans with the aim of determining whether EGCG and/or green tea extract mediates the effects of lipid metabolism or energy expenditure in skeletal muscle. A study [71] researched the effect of 3-day supplementation of $282 \mathrm{mg}$ /day EGCG on overweight subjects and found a non-significant effect on skeletal muscle lipolysis. It also found decreased lactate concentration, which suggests a shift towards a more oxidative muscle phenotype and also indicates that a longer period is necessary for the prevention of obesity [71,72]. Additionally, a systematic review on the effects on metabolic parameters such as respiratory quotient and energy expenditure concluded that EGCG could have a positive effect on both parameters, however, the authors conclude that further and larger prospective trials are needed [73].

The findings on humans suggest that EGCG alone also has a potential effect on fat oxidation. A randomized, double-blind, placebo-controlled, crossover pilot study showed that the administration of $300 \mathrm{mg}$ EGCG/day for two days decreased the respiratory quotient during the first postprandial phase, suggesting an increase in fat oxidation and a potential anti-obesity effect [74]. Another study conducted with human subjects reported a decrease in body weight and body fat as well as an increase in fat oxidation and thermogenesis; these findings were confirmed in cell culture systems and animal models of obesity [63]. Other studies and designed experiments with green tea consumption combined with resistance training aimed to determine whether the observed beneficial effects were increased with exercise. Results demonstrated that there was a decrease in body fat, waist circumference and triglyceride levels, and an increase in body mass and muscle strength [75]. In contrast, in a randomized controlled trial study, overweight or obese male subjects randomly took $400 \mathrm{mg}$ capsules of EGCG twice a day over 8 weeks. The results conclude that EGCG had no effect on insulin sensitivity, insulin secretion or glucose tolerance measured in blood extractions [50]. Therefore, well-designed and controlled clinical studies are necessary to validate the results of these human studies. Moreover, it must be stated that the concentrations used in many animal studies or the extrapolation of the doses from cell culture experiment into those equivalents in humans, greatly surpass what would be considered a physiological dose in humans. This might explain the differences in observed results between the different models and should be taken into account in future studies. 


\section{Metabolic Effects of EGCG in the Muscle and Muscle Cell Lines}

\subsection{Mitochondria and Oxidative Stress}

The main role of mitochondria is energy production. For this reason, an impairment of their function could be implicated in insulin resistance and obesity [76]. The oxygen available for the respiratory chain activity may undergo incomplete reduction giving rise to ROS that is scavenged by the antioxidant defenses of the organelle. Likewise, there are several other ROS producers that have been identified in muscle cells that are activated by different stimuli including nicotinamide adenine dinucleotide phosphate (NADPH), oxidases (NOXs), phospholipase A2 (PLA2), xanthine oxidase $(\mathrm{XO})$ and lipoxygenases [77]. Moreover, ROS can also be produced from non-muscle sources, such as immune cells, in response to muscle injures from exercise [78]. Furthermore, it has also been proposed that ROS activates ERK and/or JNK and induces autophagy in skeletal muscle [79]. The overproduction of ROS could lead to oxidative stress. To protect against this oxidative stress, enzymatic and non-enzymatic antioxidant systems could regulate ROS. The enzymatic systems, which include superoxide dismutase, glutathione peroxidase and catalase, have the capacity to convert ROS into less active molecules and prevent the transformation of these less active species into a more deleterious form. However, non-enzymatic antioxidants, such as EGCG, can protect against this undesirable effect and prevent pathological states that involve oxidative cell damage [80]. Indeed, the intake of EGCG by Wistar rats also reveals a decrease in plasma markers of oxidative stress, and an increase in antioxidant enzymes. Thus modulating and protecting from the effects of oxidant species by increasing antioxidant enzymatic systems and also due to their antioxidant capacity [81].

In skeletal muscle, the oral gavage of $100 \mathrm{mg}$ EGCG $/ \mathrm{kg} /$ day for 3 months in diabetic rats significantly reduced the expression levels of Beclin1 and dynamin-related protein 1 (DRP1) [79]. This implies that EGCG regulated mitochondrial-involved autophagy and ameliorated excessive muscle autophagy through down regulation of the ROS/ERK/JNK-p53 pathway [79]. Muscle is a major site of ATP production and energy consumption where the uptake and oxidation of glucose and fatty acids are key molecular events [64]. Moreover, EGCG has also been reported to inhibit mitochondrial oxidative phosphorylation to decrease ATP levels [82]. All these actions would result in an increase in the ADP/ATP ratio to activate AMPK, although these possibilities are still being researched.

\subsection{Endoplasmic Reticulum}

It has been shown that a high fat and sucrose diet, apart from dysregulation of lipid homeostasis, can also activate endoplasmic reticulum (ER) in skeletal muscle [83,84]. ER is an organelle that regulates a variety of post-transcriptional protein modifications, so its disruption leads to the accumulation of unfolded or misfolded proteins in the ER that affects a variety of cellular signaling processes, including energy production, inflammation and apoptosis. Several studies suggest that altered redox homeostasis in the ER causes ER stress and induces ROS production in ER and mitochondria [85,86]. If the ER stress is prolonged and cannot be restored, the functional homeostasis of the ER is impaired, which can induce an inflammatory state, protein degradation and cell death $[85,87]$. In mice fed with a high fat diet and receiving green tea extract rich in EGCG for 20 weeks, Rodriguez [66] found that there was a protective effect in muscle against oxidative stress and ER stress due to the repression of the increase in Binding immunoglobulin protein (BiP), Activating transcription factor 4 (ATF4), X-box binding protein 1s (XBP1s) and X-box binding protein $1 \mathrm{u}(\mathrm{XBP} 1 \mathrm{u})$ in skeletal muscle protecting the cell from apoptosis and cell death.

\subsection{Lipids}

Other studies have also shown that EGCG may modulate muscle lipid metabolism by increasing lipid use, suggesting that thermogenesis and fat oxidation are increased [60] and, thus, that EGCG has lipid lowering properties [88]. Human and animal studies have revealed that excessive lipid accumulation in addition to obesity could also lead to insulin resistance or heart failure. Therefore, this 
lipid accumulation deteriorates cell signaling pathways and causes cellular dysfunctions $[66,89]$. It has been shown that chronic feeding of green tea extract could be implicated in fatty acid oxidation; elevating gene expression factors involved in lipid transport and oxidation such as fatty acid translocase (FAT) /CD36, medium-chain acyl-CoA dehydrogenase (MCAD) and uncoupling protein 3 (UCP3) $[49,60]$. Another study demonstrated that the treatment of 1\% dietary EGCG for 4 weeks in mice reduced high fat diet-induced increase in body weight and body fat mass as well as increased mRNA expression of UCP2 and UCP3 in liver and skeletal muscle. These two genes are related to fatty acid oxidation, explaining the effects of EGCG on body weight gain. EGCG in this experiment also downregulates genes related to fatty acid synthesis and storage in the liver and white adipose tissue $[54,90]$. Moreover, $\beta$-oxidation in the gastrocnemius muscle of lean mice, fed with green tea, was elevated and exercise capacity was increased, as well as the expression of FAT/CD36 mRNA in skeletal muscle [60]. Friedrich [91] studied the acute effect of EGCG on oxidation and fat depots, and showed that in male C57BL/ 6 mice fed with different high fat diets, and an EGCG supplement, there was an increase of postprandial dietary fat oxidation and a decrease of dietary fat incorporation in skeletal muscle. These results were correlated with the downregulation of lipogenesis genes (ACC, FAS, SCD1) and lipid synthesis in liver and skeletal muscle in the postprandial state after 2 and 4 days of treatment.

\subsection{Glucose}

The role of EGCG in the modulation of glucose uptake and disposition has also been studied. Skeletal muscle is a key regulator of glucose homeostasis and contributes to postprandial blood glucose levels [92]. Skeletal muscle accounts for about $75 \%$ of insulin-stimulated whole-body glucose uptake [93]. To stimulate glucose uptake in the muscle cells, insulin promotes the translocation of GLUT4 from intracellular storage vesicles to the plasma membrane [94]. Many studies have focused on the regulation of the expression of genes involved in glucose uptake and insulin signaling to determine the mechanism behind the antidiabetic activities of green tea [57]. An experiment with mice fed with a high fat diet and treated with $0.32 \%$ EGCG for 16 weeks found a reduction in body weight and insulin resistance and an increase in the mRNA levels of the nuclear respiratory factor (Nrf1), medium chain acyl coA decarboxylase (Mcad), UCP3 and peroxisome proliferator $\alpha$ (PPAR- $\alpha$ ) related to lipid metabolism [49]. Serisier et al. [95] carried out an experiment with dogs and showed that green tea can affect insulin sensitivity. Obese, insulin-resistant dogs were treated orally with green tea extract ( $80 \mathrm{mg} / \mathrm{kg}$ bw per day) over 12 weeks. The results showed that insulin resistance was decreased by $20 \%$ and in skeletal muscle the expression of PPAR $\alpha$ and LPL mRNA increased; however, GLUT4 mRNA did not increase. In contrast, an experiment on Wistar rats with $0.1-0.2 \%$ dietary green tea treatment over 6 weeks concomitant with a high fructose diet showed that mRNA GLUT4 and IRS1 levels increased in muscle [96]. Similar results were found in an experiment carried out with male C57BL/6J mice fed with a high-fat diet and green and black tea supplements, where body weight gain and fat deposition in white adipose tissue were suppressed due to the stimulation of glucose uptake and the upregulation of the GLUT4 expression in the plasma membrane of muscle cells [97]. Experiments on Wistar rats revealed that EGCG attenuated free fatty-induced insulin resistance by activating the AMPK pathway [81]. Enhanced GLUT4 translocation and activation of AMPK in skeletal muscle have also been observed in lean mice treated with oolong, black or Pu-erh tea ( $2 \%$ extract as drinking fluid) for 7 days [98]. AMPK is a phosphorylating enzyme that regulates metabolic homeostasis of fatty acid and glucose metabolism in skeletal muscle and the inhibition of adipocyte lipolysis and the modulation of insulin secretion by pancreatic $\beta$-cells [99]. For this reason, there is interest in developing AMPK activators as a potential therapy for diabetes and obesity $[94,100,101]$. This AMPK activation would decrease gluconeogenesis and fatty acid synthesis while increasing catabolism, leading to a reduction in body weight [64]. Therefore, the effects of green tea rich in EGCG on glucose metabolism associated with T2D seems to be mediated in various ways, including glucose production, increased insulin secretion and insulin sensitivity, and increased uptake of glucose into skeletal muscle [102]. Various 
authors have discussed these mechanisms and their beneficial effects [103,104]. Indeed, experiments carried out on rodents have detected several other mechanisms attributed to the decrease on body weight. EGCG may modulate energy expenditure by inhibiting catechol-o-methyltransferase (COMT), which would lead to increased fat oxidation $[105,106]$. Another mechanism is the involvement of EGCG in sirtuins activation, especially Sirtuin 1 (SIRT1), which deacetylates histones and non-histone proteins including transcription factors [107]. The activation of SIRT1 in various types of polyphenols, such as EGCG, is beneficial for reducing energy absorption and increasing fat oxidation in diet-induced obesity in mice [54]. Moreover, SIRT1 is associated with the transcriptional co-factor peroxisome proliferator-activated receptor-y-coactivator $1 \alpha$ (PGC1 $\alpha)$ activation, thereby also improving the mitochondrial function and protecting against metabolic diseases $[107,108]$.

In experiments with isolated myocytes, it was found that EGCG stimulates GLUT4 translocation and results in an increased glucose uptake $[56,61,97]$. A study in male Wistar rats with an intake of EGCG during 3 weeks, also ameliorated glucose homeostasis [92]. EGCG acts as a potent antioxidant and protects against oxidant agents such as docosahexaenoic acid (DHA) in in vitro experiments by decreasing ROS levels and restring changes in mitochondrial morphology induced by DHA [109]. Moreover, other experiments with mouse C2C12 muscle cells treated with EGCG have shown a reduction in ROS levels $[110,111]$, and a beneficial effect on fatty acid-induced peripheral insulin resistance [112]. There are many mechanisms involved in such response including: inhibition of PKC activation enhanced by the AMPK cascade, IRS1 serine phosphorylation and other kinases such as ERK1/2 and p38 MAPK, essential for maximal stimulation of glucose uptake in response to insulin $[113,114]$; and finally, the suppression of lipid accumulation via the AMPK/ACC signaling pathway [112,115]. In mouse C2C12 myotubes, the inhibition of AMPK following glutamate dehydrogenase (GDH) activation was reversed by EGCG. GDH senses mitochondrial energy supply, and its stimulation in primary human myotubes caused lowering of insulin-induced 2-deoxy-glucose uptake, which was partially counteracted by EGCG. Thus, mitochondrial energy provision, through anaplerotic input via GDH, influences the activity of the cytosolic energy sensor AMPK [116]. In addition, an in vitro experiment with L6 cells with insulin resistance and treated with $20 \mu \mathrm{M}$ EGCG, demonstrated an improvement in glucose uptake by GLUT 4 translocation to the plasma membrane [94,117], which depended on the key regulator AMPK [118] and PI3-K/Akt activation $[56,117,119]$. Other studies on EGCG reported that it stimulates the MAPK pathway and the Nrf2 transcription factor leading to the transcription activation of the ARE-mediated Phase II genes induction [120].

Some of EGCG effects are mediated by epigenetic mechanisms because EGCG inhibits directly DNMT by interacting with the catalytic site of the DNMT molecule [121]. Studies with structural analogues of EGCG suggest the importance of D and B ring structures in the inhibitory activity. Molecular modelling studies also support the direct inhibitory effect of EGCG on DNMT; EGCG forms hydrogen bonds with Pro(1223), Glu(1265), Cys(1225), Ser(1229) and $\operatorname{Arg}(1309)$ in the catalytic pocket of DNMT [68]. EGCG also acts by inhibiting histone acetyl transferase activity and NF-kB activation [122].

\section{Future Approaches}

As exposed in this review, there are numerous studies focusing on EGCG and its effects on the many metabolic disturbances that affect the skeletal muscle in obesity and T2D, however, more research must be done to identify the specific metabolic pathways implicated on its response or the appropriate treatment for human patients. Moreover, the low systemic bioavailability of EGCG raises doubts about the feasibility of this molecule for the treatment or prevention of particular diseases.

In order to overcome the problem of EGCG instability and low bioavailability, several studies have tried the use of nanocarriers, such as liposomes and gold nanoparticles, which have shown to greatly increase the effects of EGCG in particular diseases [123]. On the other hand, scientists are studying the possibility of combining different bioactive ingredients with known beneficial activities 
on the causes of obesity or the inflammatory state. In this sense, there are studies focusing on the combination of these ingredients in order to obtain additive or synergic effects that could increase the overall effect of the individual ingredients [124,125]. Specifically for EGCG, it has been shown that combining EGCG with other bioactive ingredients with similar activities, and its supplementation to obese individuals, improved many of the obesity related parameters [126,127].

\section{Conclusions}

In conclusion, EGCG may be useful to treat obesity by re-sensitizing insulin-resistant muscle, increasing muscle lipid oxidation and stimulating the glucose uptake of muscle cells. Likewise, EGCG may revert the increase of ROS production, ER stress and protein degradation in skeletal muscle in obesity by regulating mitochondrial-involved autophagy and ameliorating excessive muscle autophagy (Figure 2). Despite being a potent antioxidant, EGCG does not seem to act in vivo as conventional hydrogen-donating antioxidants due to its low bioavailability. The circulating EGCG concentration is in the nanoM interval, similar to hormones. Thus, rather than acting as a chemical antioxidant, in vivo EGCG generates signals for inducing protective enzymes and may exert modulatory actions in cells acting as signaling molecules and/or regulating gene expression. In this sense, EGCG, among other mechanisms, up-regulates genes encoding for phase II enzymes with antioxidant response elements (AREs) in the promoter region; has insulin-mimetic actions via the PI3K/Akt signaling pathway; activates AMPK, an energy-responsive and redox sensing enzyme; and inhibits DNA methyltransferases and histone acetyl transferases, thus mediating epigenetic mechanisms.

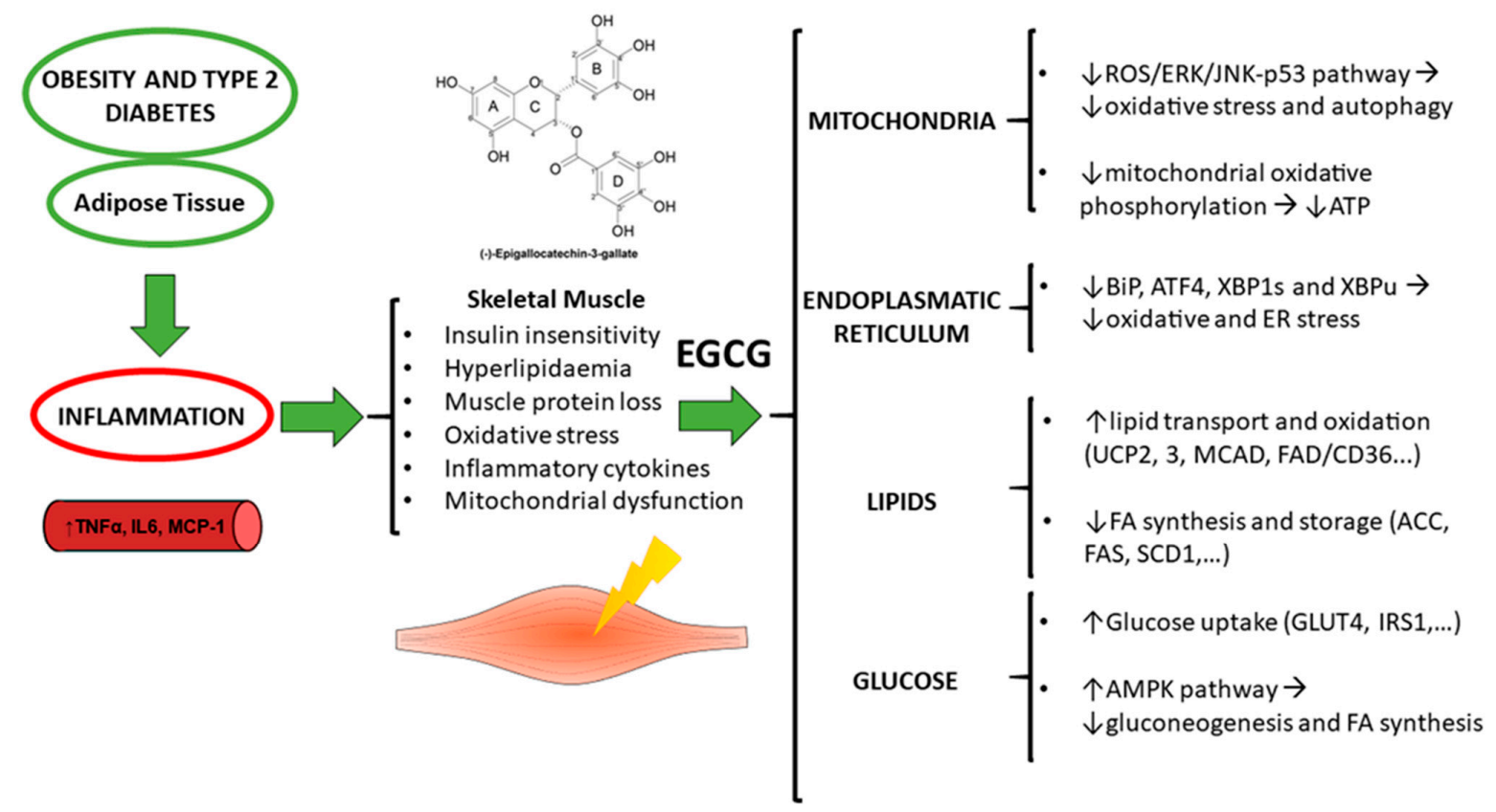

Figure 2. Summary of the effects of (-)-Epigallocatechin-3-gallate on the modulation of muscle homeostasis in obesity and type 2 diabetes. Arrows indicate an increase $(\uparrow)$ or decrease $(\downarrow)$ of that particular molecule or the pathway's activity.

It would be interesting to apply these results to counteract obesity, where EGCG could be used as a complement to sport programmes and good eating habits to obtain better responses against obesity.

Funding: This research was funded by the Spanish Ministerio de Economía y Competitividad (grant numbers AGL2013-40707-R and AGL2016-77105-R).

Conflicts of Interest: The authors declare no conflict of interest. 


\section{References}

1. $\quad$ Bhagwat, S.; Haytowitz, D.B.; Holden, J.M. USDA Database for the Flavonoid Content of Selected Foods Release 3; U.S. Department of Argiculture: Washington, DC, USA, 2011; pp. 1-156.

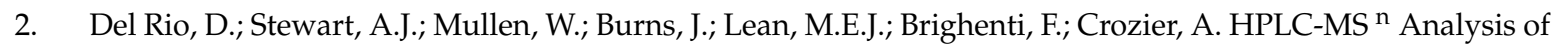
Phenolic Compounds and Purine Alkaloids in Green and Black Tea. J. Agric. Food Chem. 2004, 52, 2807-2815. [CrossRef]

3. Kanwar, J.; Taskeen, M.; Mohammad, I.; Huo, C.; Chan, T.H.; Dou, Q.P. Recent advances on tea polyphenols. Front. Biosci. 2012, 4, 111-131. [CrossRef]

4. Renaud, J.; Nabavi, S.M.; Daglia, M.; Nabavi, S.F.; Martinoli, M.-G. Epigallocatechin-3-gallate, a promising molecule for Parkinson's disease? Rejuvenation Res. 2015, 18, 257-269. [CrossRef] [PubMed]

5. Stalmach, A.; Troufflard, S.; Serafini, M.; Crozier, A. Absorption, metabolism and excretion of Choladi green tea flavan-3-ols by humans. Mol. Nutr. Food Res. 2009, 53, 44-53. [CrossRef] [PubMed]

6. Del Rio, D.; Rodriguez-Mateos, A.; Spencer, J.P.E.; Tognolini, M.; Borges, G.; Crozier, A. Dietary (Poly)phenolics in Human Health: Structures, Bioavailability, and Evidence of Protective Effects Against Chronic Diseases. Antioxid. Redox Signal. 2013, 18, 1818-1892. [CrossRef] [PubMed]

7. Shahrzad, S.; Bitsch, I. Determination of gallic acid and its metabolites in human plasma and urine by high-performance liquid chromatography. J. Chromatogr. B. Biomed. Sci. Appl. 1998, 705, 87-95. [CrossRef]

8. Shahrzad, S.; Aoyagi, K.; Winter, A.; Koyama, A.; Bitsch, I. Pharmacokinetics of gallic acid and its relative bioavailability from tea in healthy humans. J. Nutr. 2001, 131, 1207-1210. [CrossRef] [PubMed]

9. Chow, H.H.; Cai, Y.; Alberts, D.S.; Hakim, I.; Dorr, R.; Shahi, F.; Crowell, J.A.; Yang, C.S.; Hara, Y. Phase I pharmacokinetic study of tea polyphenols following single-dose administration of epigallocatechin gallate and polyphenon E. Cancer Epidemiol. Biomar. Prev. 2001, 10, 53-58.

10. Lee, M.-J.; Maliakal, P.; Chen, L.; Meng, X.; Bondoc, F.Y.; Prabhu, S.; Lambert, G.; Mohr, S.; Yang, C.S. Pharmacokinetics of tea catechins after ingestion of green tea and (-)-epigallocatechin-3-gallate by humans: Formation of different metabolites and individual variability. Cancer Epidemiol. Biomark. Prev. 2002, 11, 1025-1032.

11. Meng, X.; Sang, S.; Zhu, N.; Lu, H.; Sheng, S.; Lee, M.-J.; Ho, C.-T.; Yang, C.S. Identification and characterization of methylated and ring-fission metabolites of tea catechins formed in humans, mice, and rats. Chem. Res. Toxicol. 2002, 15, 1042-1050. [CrossRef]

12. Ullmann, U.; Haller, J.; Decourt, J.D.; Girault, J.; Spitzer, V.; Weber, P. Plasma-kinetic characteristics of purified and isolated green tea catechin epigallocatechin gallate (EGCG) after 10 days repeated dosing in healthy volunteers. Int. J. Vitam. Nutr. Res. 2004, 74, 269-278. [CrossRef] [PubMed]

13. Okushio, K.; Suzuki, M.; Matsumoto, N.; Nanjo, F.; Hara, Y. Identification of (-)-Epicatechin Metabolites and Their Metabolic Fate in the Rat. Drug Metab. Dispos. 1999, 27, 309-316. [PubMed]

14. Eaton, J.D.; Williamson, M.P. Multi-site binding of epigallocatechin gallate to human serum albumin measured by NMR and isothermal titration calorimetry. Biosci. Rep. 2017, 37, BSR20170209. [CrossRef] [PubMed]

15. Kim, S.; Lee, M.J.; Hong, J.; Li, C.; Smith, T.J.; Yang, G.Y.; Seril, D.N.; Yang, C.S. Plasma and tissue levels of tea catechins in rats and mice during chronic consumption of green tea polyphenols. Nutr. Cancer 2000, 37, 41-48. [CrossRef] [PubMed]

16. Lin, L.-C.; Wang, M.-N.; Tseng, T.-Y.; Sung, J.-S.; Tsai, T.-H. Pharmacokinetics of (-)-epigallocatechin-3-gallate in conscious and freely moving rats and its brain regional distribution. J. Agric. Food Chem. 2007, 55, 1517-1524. [CrossRef] [PubMed]

17. Suganuma, M.; Okabe, S.; Oniyama, M.; Tada, Y.; Ito, H.; Fujiki, H. Wide distribution of $[3 \mathrm{H}](-)$-epigallocatechin gallate, a cancer preventive tea polyphenol, in mouse tissue. Carcinogenesis 1998, 19, 1771-1776. [CrossRef] [PubMed]

18. Kohri, T.; Matsumoto, N.; Yamakawa, M.; Suzuki, M.; Nanjo, F.; Hara, Y.; Oku, N. Metabolic fate of (-)-[4-(3)H]epigallocatechin gallate in rats after oral administration. J. Agric. Food Chem. 2001, 49, 4102-4112. [CrossRef]

19. Unno, T.; Kondo, K.; Itakura, H.; Takeo, T. Analysis of (-)-epigallocatechin gallate in human serum obtained after ingesting green tea. Biosci. Biotechnol. Biochem. 1996, 60, 2066-2068. [CrossRef] 
20. Henning, S.M.; Niu, Y.; Liu, Y.; Lee, N.H.; Hara, Y.; Thames, G.D.; Minutti, R.R.; Carpenter, C.L.; Wang, H.; Heber, D. Bioavailability and antioxidant effect of epigallocatechin gallate administered in purified form versus as green tea extract in healthy individuals. J. Nutr. Biochem. 2005, 16, 610-616. [CrossRef]

21. Clifford, M.; van der Hooft, J.; Crozier, A. Human studies on the absorption, distribution, metabolism, and excretion of tea polyphenols. Am. J. Clin. Nutr. 2013, 98, 1619S-1630S. [CrossRef]

22. Auger, C.; Mullen, W.; Hara, Y.; Crozier, A. Bioavailability of polyphenon E flavan-3-ols in humans with an ileostomy. J. Nutr. 2008, 138, 1535S-1542S. [CrossRef] [PubMed]

23. Kida, K.; Suzuki, M.; Matsumoto, N.; Nanjo, F.; Hara, Y. Identification of biliary metabolites of (-)-epigallocatechin gallate in rats. J. Agric. Food Chem. 2000, 48, 4151-4155. [CrossRef] [PubMed]

24. Kohri, T.; Nanjo, F.; Suzuki, M.; Seto, R.; Matsumoto, N.; Yamakawa, M.; Hojo, H.; Hara, Y.; Desai, D.; Amin, S.; et al. Synthesis of (-)-[4-3H]epigallocatechin gallate and its metabolic fate in rats after intravenous administration. J. Agric. Food Chem. 2001, 49, 1042-1048. [CrossRef] [PubMed]

25. Del Rio, D.; Calani, L.; Cordero, C.; Salvatore, S.; Pellegrini, N.; Brighenti, F. Bioavailability and catabolism of green tea flavan-3-ols in humans. Nutrition 2010, 26, 1110-1116. [CrossRef] [PubMed]

26. Stalmach, A.; Mullen, W.; Steiling, H.; Williamson, G.; Lean, M.E.J.; Crozier, A. Absorption, metabolism, and excretion of green tea flavan-3-ols in humans with an ileostomy. Mol. Nutr. Food Res. 2010, 54, 323-334. [CrossRef] [PubMed]

27. World Health Organization (WHO) Obesity and Overweight, Factsheet No. 311. Available online: http: / / www.who.int/mediacentre/factsheets/fs311/en/ (accessed on 13 February 2018).

28. Fruh, S.M. Obesity: Risk factors, complications, and strategies for sustainable long-term weight management. J. Am. Assoc. Nurse Pract. 2017, 29, S3-S14. [CrossRef] [PubMed]

29. Wang, S.; Moustaid-Moussa, N.; Chen, L.; Mo, H.; Shastri, A.; Su, R.; Bapat, P.; Kwun, I.S.; Shen, C.L. Novel insights of dietary polyphenols and obesity. J. Nutr. Biochem. 2014, 25, 1-18. [CrossRef] [PubMed]

30. Grimble, R.F. Gene Polymorphisms, Nutrition, and the Inflammatory Response. In Nutritional Genomics: Impact on Health and Disease; Brigelius-Flohé, R., Joost, H.G., Eds.; Wiley-Blackwell: Hoboken, NJ, USA, 2006; pp. 1-442, ISBN 9783527312948.

31. Liu, T.; Zhang, L.; Joo, D.; Sun, S.-C. NF-кB signaling in inflammation. Signal Transduct. Target. Ther. 2017, 2, 17023. [CrossRef] [PubMed]

32. McArdle, M.A.; Finucane, O.M.; Connaughton, R.M.; McMorrow, A.M.; Roche, H.M. Mechanisms of obesity-induced inflammation and insulin resistance: Insights into the emerging role of nutritional strategies. Front. Endocrinol. 2013, 4, 52. [CrossRef] [PubMed]

33. Spranger, J.; Kroke, A.; Möhlig, M.; Hoffmann, K.; Bergmann, M.M.; Ristow, M.; Boeing, H.; Pfeiffer, A.F.H. Inflammatory cytokines and the risk to develop type 2 diabetes: Results of the prospective population-based European Prospective Investigation into Cancer and Nutrition (EPIC)-Potsdam Study. Diabetes 2003, 52, 812-817. [CrossRef] [PubMed]

34. Pedersen, B.K.; Febbraio, M.A. Muscle as an endocrine organ: Focus on muscle-derived interleukin-6. Physiol. Rev. 2008, 88, 1379-1406. [CrossRef] [PubMed]

35. Rehman, K.; Akash, M.S.H.; Liaqat, A.; Kamal, S.; Qadir, M.I.; Rasul, A. Role of Interleukin-6 in Development of Insulin Resistance and Type 2 Diabetes Mellitus. Crit. Rev. Eukaryot. Gene Expr. 2017, 27, 229-236. [CrossRef] [PubMed]

36. Hoene, M.; Weigert, C. The role of interleukin-6 in insulin resistance, body fat distribution and energy balance. Obes. Rev. 2008, 9, 20-29. [CrossRef] [PubMed]

37. Sindhu, S.; Thomas, R.; Shihab, P.; Sriraman, D.; Behbehani, K.; Ahmad, R. Obesity Is a Positive Modulator of IL-6R and IL-6 Expression in the Subcutaneous Adipose Tissue: Significance for Metabolic Inflammation. PLoS ONE 2015, 10, e0133494. [CrossRef] [PubMed]

38. Palanivel, R.; Fullerton, M.D.; Galic, S.; Honeyman, J.; Hewitt, K.A.; Jorgensen, S.B.; Steinberg, G.R. Reduced Socs 3 expression in adipose tissue protects female mice against obesity-induced insulin resistance. Diabetologia 2012, 55, 3083-3093. [CrossRef] [PubMed]

39. Yang, Z.; Hulver, M.; McMillan, R.P.; Cai, L.; Kershaw, E.E.; Yu, L.; Xue, B.; Shi, H. Regulation of Insulin and Leptin Signaling by Muscle Suppressor of Cytokine Signaling 3 (SOCS3). PLoS ONE 2012, 7, e47493. [CrossRef] [PubMed]

40. Boucher, J.; Kleinridders, A.; Kahn, C.R. Insulin Receptor Signaling in Normal and Insulin-Resistant States. Cold Spring Harb. Perspect. Biol. 2014, 6, a009191. [CrossRef] 
41. Pedroso, J.A.B.; Ramos-Lobo, A.M.; Donato, J. SOCS3 as a future target to treat metabolic disorders. Hormones 2018. [CrossRef] [PubMed]

42. Karimfar, M.H.; Haghani, K.; Babakhani, A.; Bakhtiyari, S. Rosiglitazone, but Not Epigallocatechin-3-Gallate, Attenuates the Decrease in PGC-1 $\alpha$ Protein Levels in Palmitate-Induced Insulin-Resistant C2C12 Cells. Lipids 2015, 50, 521-528. [CrossRef] [PubMed]

43. Aggarwal, B.B. Targeting inflammation-induced obesity and metabolic diseases by curcumin and other nutraceuticals. Annu. Rev. Nutr. 2010, 30, 173-199. [CrossRef] [PubMed]

44. Lee, Y.-M.; Yoon, Y.; Yoon, H.; Park, H.-M.; Song, S.; Yeum, K.-J. Dietary Anthocyanins against Obesity and Inflammation. Nutrients 2017, 9, 1049. [CrossRef] [PubMed]

45. Torres-Fuentes, C.; Schellekens, H.; Dinan, T.G.; Cryan, J.F. A natural solution for obesity: Bioactives for the prevention and treatment of weight gain. A review. Am. J. Clin. Nutr. 2015, 18, 49-65. [CrossRef] [PubMed]

46. Asghar, A.; Sheikh, N. Role of immune cells in obesity induced low grade inflammation and insulin resistance. Cell. Immunol. 2017, 315, 18-26. [CrossRef] [PubMed]

47. Deng, T.; Lyon, C.J.; Bergin, S.; Caligiuri, M.A.; Hsueh, W.A. Obesity, Inflammation, and Cancer. Annu. Rev. Pathol. Mech. Dis. 2016, 11, 421-449. [CrossRef] [PubMed]

48. Saltiel, A.R.; Olefsky, J.M. Inflammatory mechanisms linking obesity and metabolic disease. J. Clin. Investig. 2017, 127, 1-4. [CrossRef] [PubMed]

49. Sae-tan, S.; Grove, K.A.; Kennett, M.J.; Lambert, J.D. (-)-Epigallocatechin-3-gallate increases the expression of genes related to fat oxidation in the skeletal muscle of high fat-fed mice. Food Funct. 2011, 2, 111-116. [CrossRef] [PubMed]

50. Brown, A.L.; Lane, J.; Coverly, J.; Stocks, J.; Jackson, S.; Stephen, A.; Bluck, L.; Coward, A.; Hendrickx, H. Effects of dietary supplementation with the green tea polyphenol epigallocatechin-3-gallate on insulin resistance and associated metabolic risk factors: Randomized controlled trial. Br. J. Nutr. 2009, 101, 886-894. [CrossRef] [PubMed]

51. Santamarina, A.B.; Oliveira, J.L.; Silva, F.P.; Carnier, J.; Mennitti, L.V.; Santana, A.A.; de Souza, G.H.I.; Ribeiro, E.B.; Oller do Nascimento, C.M.; Lira, F.S.; et al. Green Tea Extract Rich in Epigallocatechin-3-Gallate Prevents Fatty Liver by AMPK Activation via LKB1 in Mice Fed a High-Fat Diet. PLoS ONE 2015, 10, e0141227. [CrossRef] [PubMed]

52. Bose, M.; Lambert, J.D.; Ju, J.; Reuhl, K.R.; Shapses, S.A.; Yang, C.S. The Major Green Tea Polyphenol, (-)-Epigallocatechin-3-Gallate, Inhibits Obesity, Metabolic Syndrome, and Fatty Liver Disease in High-Fat-Fed Mice. J. Nutr. 2008, 138, 1677-1683. [CrossRef] [PubMed]

53. Chen, N.; Bezzina, R.; Hinch, E.; Lewandowski, P.A.; Cameron-Smith, D.; Mathai, M.L.; Jois, M.; Sinclair, A.J.; Begg, D.P.; Wark, J.D.; et al. Green tea, black tea, and epigallocatechin modify body composition, improve glucose tolerance, and differentially alter metabolic gene expression in rats fed a high-fat diet. Nutr. Res. 2009, 29, 784-793. [CrossRef] [PubMed]

54. Klaus, S.; Pultz, S.; Thone-Reineke, C.; Wolfram, S. Epigallocatechin gallate attenuates diet-induced obesity in mice by decreasing energy absorption and increasing fat oxidation. Int. J. Obes. Relat. Metab. Disord. 2005, 29, 615-623. [CrossRef] [PubMed]

55. Li, H.; Kek, H.C.; Lim, J.; Gelling, R.W.; Han, W. Green tea (-)-epigallocatechin-3-gallate counteracts daytime overeating induced by high-fat diet in mice. Mol. Nutr. Food Res. 2016, 60, 2565-2575. [CrossRef] [PubMed]

56. Ueda, M.; Nishiumi, S.; Nagayasu, H.; Fukuda, I.; Yoshida, K.; Ashida, H. Epigallocatechin gallate promotes GLUT4 translocation in skeletal muscle. Biochem. Biophys. Res. Commun. 2008, 377, 286-290. [CrossRef] [PubMed]

57. Sae-tan, S.; Grove, K.A.; Lambert, J.D. Weight control and prevention of metabolic syndrome by green tea. Pharmacol. Res. 2011, 64, 146-154. [CrossRef] [PubMed]

58. Yu, C.; Chen, Y.; Cline, G.W.; Zhang, D.; Zong, H.; Wang, Y.; Bergeron, R.; Kim, J.K.; Cushman, S.W.; Cooney, G.J.; et al. Mechanism by which fatty acids inhibit insulin activation of insulin receptor substrate-1 (IRS-1)-associated phosphatidylinositol 3-kinase activity in muscle. J. Biol. Chem. 2002, 277, 50230-50236. [CrossRef] [PubMed]

59. Lu, C.; Zhu, W.; Shen, C.-L.; Gao, W. Green Tea Polyphenols Reduce Body Weight in Rats by Modulating Obesity-Related Genes. PLoS ONE 2012, 7, e0038332. [CrossRef] [PubMed] 
60. Murase, T.; Haramizu, S.; Shimotoyodome, A.; Nagasawa, A.; Tokimitsu, I. Green tea extract improves endurance capacity and increases muscle lipid oxidation in mice. Am. J. Physiol. Regul. Integr. Comp. Physiol. 2005, 288, R708-R715. [CrossRef] [PubMed]

61. Ashida, H.; Furuyashiki, T.; Nagayasu, H.; Bessho, H.; Sakakibara, H.; Hashimoto, T.; Kanazawa, K. Anti-obesity actions of green tea: Possible involvements in modulation of the glucose uptake system and suppression of the adipogenesis-related transcription factors. BioFactors 2004, 22, 135-140. [CrossRef]

62. Kim, H.-J.; Jeon, S.-M.; Lee, M.-K.; Jung, U.J.; Shin, S.-K.; Choi, M.-S. Antilipogenic effect of green tea extract in C57BL/6J-Lepob/ob mice. Phyther. Res. 2009, 23, 467-471. [CrossRef]

63. Wolfram, S.; Wang, Y.; Thielecke, F. Anti-obesity effects of green tea: From bedside to bench. Mol. Nutr. Food Res. 2006, 50, 176-187. [CrossRef]

64. Yang, C.S.; Zhang, J.; Zhang, L.; Huang, J.; Wang, Y. Mechanisms of Body Weight Reduction and Metabolic Syndrome Alleviation by Tea. Mol. Nutr. Food Res. 2016, 60, 160-174. [CrossRef] [PubMed]

65. Ramadan, G.; El-Beih, N.M.; Abd El-Ghffar, E.A. Modulatory effects of black v. green tea aqueous extract on hyperglycaemia, hyperlipidaemia and liver dysfunction in diabetic and obese rat models. Br. J. Nutr. 2009, 102, 1611-1619. [CrossRef] [PubMed]

66. Rodriguez, J.; Gilson, H.; Jamart, C.; Naslain, D.; Pierre, N.; Deldicque, L.; Francaux, M. Pomegranate and green tea extracts protect against ER stress induced by a high-fat diet in skeletal muscle of mice. Eur. J. Nutr. 2015, 54, 377-389. [CrossRef] [PubMed]

67. Yan, J.; Zhao, Y.; Suo, S.; Liu, Y.; Zhao, B. Green tea catechins ameliorate adipose insulin resistance by improving oxidative stress. Free Radic. Biol. Med. 2012, 52, 1648-1657. [CrossRef] [PubMed]

68. Fang, M.Z.; Wang, Y.; Ai, N.; Hou, Z.; Sun, Y.; Lu, H.; Welsh, W.; Yang, C.S. Tea polyphenol (-)-epigallocatechin-3-gallate inhibits DNA methyltransferase and reactivates methylation-silenced genes in cancer cell lines. Cancer Res. 2003, 63, 7563-7570.

69. Li, Y.; Tollefsbol, T.O. Impact on DNA methylation in cancer prevention and therapy by bioactive dietary components. Curr. Med. Chem. 2010, 17, 2141-2151. [CrossRef]

70. Grove, K.A.; Lambert, J.D. Laboratory, Epidemiological, and Human Intervention Studies Show That Tea (Camellia sinensis) May Be Useful in the Prevention of Obesity. J. Nutr. 2010, 140, 446-453. [CrossRef] [PubMed]

71. Most, J.; van Can, J.G.P.; van Dijk, J.-W.; Goossens, G.H.; Jocken, J.; Hospers, J.J.; Bendik, I.; Blaak, E.E. A 3-day EGCG-supplementation reduces interstitial lactate concentration in skeletal muscle of overweight subjects. Sci. Rep. 2016, 5, 17896. [CrossRef] [PubMed]

72. Corpeleijn, E.; Saris, W.H.M.; Blaak, E.E. Metabolic flexibility in the development of insulin resistance and type 2 diabetes: Effects of lifestyle. Obes. Rev. 2009, 10, 178-193. [CrossRef] [PubMed]

73. Kapoor, M.P.; Sugita, M.; Fukuzawa, Y.; Okubo, T. Physiological effects of epigallocatechin-3-gallate (EGCG) on energy expenditure for prospective fat oxidation in humans: A systematic review and meta-analysis. J. Nutr. Biochem. 2017, 43, 1-10. [CrossRef]

74. Boschmann, M.; Thielecke, F. The effects of epigallocatechin-3-gallate on thermogenesis and fat oxidation in obese men: A pilot study. J. Am. Coll. Nutr. 2007, 26, 389S-395S. [CrossRef] [PubMed]

75. Cardoso, G.A.; Salgado, J.M.; de Castro Cesar, C.; Donado-Pestana, C.M. The effects of green tea consumption and resistance training on body composition and resting metabolic rate in overweight or obese women. J. Med. Food 2013, 16, 120-127. [CrossRef] [PubMed]

76. Porter, C.; Wall, B.T. Skeletal muscle mitochondrial function: Is it quality or quantity that makes the difference in insulin resistance? J. Physiol. 2012, 590, 5935-5936. [CrossRef] [PubMed]

77. Steinbacher, P.; Eckl, P. Impact of Oxidative Stress on Exercising Skeletal Muscle. Biomolecules 2015, 5, 356-377. [CrossRef] [PubMed]

78. Powers, S.K.; Jackson, M.J. Exercise-Induced Oxidative Stress: Cellular Mechanisms and Impact on Muscle Force Production. Physiol. Rev. 2010, 88, 1243-1276. [CrossRef] [PubMed]

79. Yan, J.; Feng, Z.; Liu, J.; Shen, W.; Wang, Y.; Wertz, K.; Weber, P.; Long, J.; Liu, J. Enhanced autophagy plays a cardinal role in mitochondrial dysfunction in type 2 diabetic Goto-Kakizaki (GK) rats: Ameliorating effects of (-)-epigallocatechin-3-gallate. J. Nutr. Biochem. 2012, 23, 716-724. [CrossRef] [PubMed]

80. Dorta, D.J.; Pigoso, A.A.; Mingatto, F.E.; Rodrigues, T.; Pestana, C.R.; Uyemura, S.A.; Santos, A.C.; Curti, C. Antioxidant activity of flavonoids in isolated mitochondria. Phyther. Res. 2008, 22, 1213-1218. [CrossRef] 
81. Li, Y.; Zhao, S.; Zhang, W.; Zhao, P.; He, B.; Wu, N.; Han, P. Epigallocatechin-3-O-gallate (EGCG) attenuates FFAs-induced peripheral insulin resistance through AMPK pathway and insulin signaling pathway in vivo. Diabetes Res. Clin. Pract. 2011, 93, 205-214. [CrossRef]

82. Valenti, D.; de Bari, L.; Manente, G.A.; Rossi, L.; Mutti, L.; Moro, L.; Vacca, R.A. Negative modulation of mitochondrial oxidative phosphorylation by epigallocatechin-3 gallate leads to growth arrest and apoptosis in human malignant pleural mesothelioma cells. Biochim. Biophys. Acta 2013, 1832, 2085-2096. [CrossRef]

83. Deldicque, L.; Cani, P.D.; Philp, A.; Raymackers, J.-M.; Meakin, P.J.; Ashford, M.L.J.; Delzenne, N.M.; Francaux, M.; Baar, K. The unfolded protein response is activated in skeletal muscle by high-fat feeding: Potential role in the downregulation of protein synthesis. Am. J. Physiol. Endocrinol. Metab. 2010, 299, E695-E705. [CrossRef]

84. Pierre, N.; Deldicque, L.; Barbé, C.; Naslain, D.; Cani, P.D.; Francaux, M. Toll-Like Receptor 4 Knockout Mice Are Protected against Endoplasmic Reticulum Stress Induced by a High-Fat Diet. PLoS ONE 2013, 8, e65061. [CrossRef] [PubMed]

85. Zhang, K.; Kaufman, R.J. From endoplasmic-reticulum stress to the inflammatory response. Nature 2008, 454, 455-462. [CrossRef] [PubMed]

86. Cao, S.S.; Kaufman, R.J. Endoplasmic Reticulum Stress and Oxidative Stress in Cell Fate Decision and Human Disease. Antioxid. Redox Signal. 2014, 21, 396-413. [CrossRef] [PubMed]

87. Gandeboeuf, D.; Dupre, C.; Roeckel-Drevet, P.; Nicolas, P.; Chevalier, G. Typing Tuber ectomycorrhizae by polymerase chain amplification of the internal transcribed spacer of rDNA and the sequence characterized amplified region markers. Can. J. Microbiol. 1997, 43, 723-728. [CrossRef]

88. Pajuelo, D.; Diaz, S.; Quesada, H.; Fernandez-Iglesias, A.; Mulero, M.; Arola-Arnal, A.; Salvado, M.J.; Blade, C.; Arola, L. Acute administration of grape seed proanthocyanidin extract modulates energetic metabolism in skeletal muscle and BAT mitochondria. J. Agric. Food Chem. 2011, 59, 4279-4287. [CrossRef] [PubMed]

89. Tsiotra, P.C.; Tsigos, C. Stress, the endoplasmic reticulum, and insulin resistance. Ann. N. Y. Acad. Sci. 2006, 1083, 63-76. [CrossRef]

90. Wolfram, S.; Raederstorff, D.; Wang, Y.; Teixeira, S.R.; Elste, V.; Weber, P. TEAVIGO ${ }^{\mathrm{TM}}$ (Epigallocatechin Gallate) Supplementation Prevents Obesity in Rodents by Reducing Adipose Tissue Mass. Ann. Nutr. Metab. 2005, 49, 54-63. [CrossRef]

91. Friedrich, M.; Petzke, K.J.; Raederstorff, D.; Wolfram, S.; Klaus, S. Acute effects of epigallocatechin gallate from green tea on oxidation and tissue incorporation of dietary lipids in mice fed a high-fat diet. Int. J. Obes. 2012, 36, 735-743. [CrossRef]

92. Keske, M.A.; Ng, H.L.H.; Premilovac, D.; Rattigan, S.; Kim, J.; Munir, K.; Yang, P.; Quon, M.J. Vascular and Metabolic Actions of the Green Tea Polyphenol Epigallocatechin Gallate. Curr. Med. Chem. 2015, 22, 59-69. [CrossRef] [PubMed]

93. Kumar, N.; Kaushik, N.K.; Park, G.; Choi, E.H.; Uhm, H.S. Enhancement of glucose uptake in skeletal muscle L6 cells and insulin secretion in pancreatic hamster-insulinoma-transfected cells by application of non-thermal plasma jet. Appl. Phys. Lett. 2013, 103, 203701. [CrossRef]

94. Yamashita, Y.; Wang, L.; Nanba, F.; Ito, C.; Toda, T.; Ashida, H. Procyanidin Promotes Translocation of Glucose Transporter 4 in Muscle of Mice through Activation of Insulin and AMPK Signaling Pathways. PLoS ONE 2016, 11, e0161704. [CrossRef] [PubMed]

95. Serisier, S.; Leray, V.; Poudroux, W.; Magot, T.; Ouguerram, K.; Nguyen, P. Effects of green tea on insulin sensitivity, lipid profile and expression of PPARalpha and PPARgamma and their target genes in obese dogs. Br. J. Nutr. 2008, 99, 1208-1216. [CrossRef] [PubMed]

96. Cao, H.; Hininger-Favier, I.; Kelly, M.A.; Benaraba, R.; Dawson, H.D.; Coves, S.; Roussel, A.M.; Anderson, R.A. Green Tea Polyphenol Extract Regulates the Expression of Genes Involved in Glucose Uptake and Insulin Signaling in Rats Fed a High Fructose Diet. J. Agric. Food Chem. 2007, 55, 6372-6378. [CrossRef] [PubMed]

97. Nishiumi, S.; Bessyo, H.; Kubo, M.; Aoki, Y.; Tanaka, A.; Yoshida, K.; Ashida, H. Green and black tea suppress hyperglycemia and insulin resistance by retaining the expression of glucose transporter 4 in muscle of high-fat diet-fed C57BL/6J mice. J. Agric. Food Chem. 2010, 58, 12916-12923. [CrossRef] [PubMed]

98. Yamashita, Y.; Wang, L.; Tinshun, Z.; Nakamura, T.; Ashida, H. Fermented tea improves glucose intolerance in mice by enhancing translocation of glucose transporter 4 in skeletal muscle. J. Agric. Food Chem. 2012, 60, 11366-11371. [CrossRef] 
99. Yuliana, N.D.; Korthout, H.; Wijaya, C.H.; Kim, H.K.; Verpoorte, R. Plant-derived food ingredients for stimulation of energy expenditure. Crit. Rev. Food Sci. Nutr. 2014, 54, 373-388. [CrossRef] [PubMed]

100. Carling, D.; Thornton, C.; Woods, A.; Sanders, M.J. AMP-activated protein kinase: New regulation, new roles? Biochem. J. 2012, 445, 11-27. [CrossRef] [PubMed]

101. O'Neill, H.M.; Holloway, G.P.; Steinberg, G.R. AMPK regulation of fatty acid metabolism and mitochondrial biogenesis: Implications for obesity. Mol. Cell. Endocrinol. 2013, 366, 135-151. [CrossRef]

102. Thielecke, F.; Boschmann, M. The potential role of green tea catechins in the prevention of the metabolic syndrome-A review. Phytochemistry 2009, 70, 11-24. [CrossRef]

103. Crespy, V.; Williamson, G. A review of the health effects of green tea catechins in in vivo animal models. J. Nutr. 2004, 134, 3431S-3440S. [CrossRef]

104. Kao, Y.-H.; Chang, H.-H.; Lee, M.-J.; Chen, C.-L. Tea, obesity, and diabetes. Mol. Nutr. Food Res. 2006, 50, 188-210. [CrossRef]

105. Dulloo, A.G.; Duret, C.; Rohrer, D.; Girardier, L.; Mensi, N.; Fathi, M.; Chantre, P.; Vandermander, J. Efficacy of a green tea extract rich in catechin polyphenols and caffeine in increasing 24-h energy expenditure and fat oxidation in humans. Am. J. Clin. Nutr. 1999, 70, 1040-1045. [CrossRef] [PubMed]

106. Hursel, R.; Janssens, P.L.H.R.; Bouwman, F.G.; Mariman, E.C.; Westerterp-Plantenga, M.S. The Role of Catechol-O-Methyl Transferase Val(108/158)Met Polymorphism (rs4680) in the Effect of Green Tea on Resting Energy Expenditure and Fat Oxidation: A Pilot Study. PLoS ONE 2014, 9, e106220. [CrossRef] [PubMed]

107. Chung, S.; Yao, H.; Caito, S.; Hwang, J.; Arunachalam, G.; Rahman, I. Regulation of SIRT1 in cellular functions: Role of polyphenols. Arch. Biochem. Biophys. 2010, 501, 79-90. [CrossRef] [PubMed]

108. Lagouge, M.; Argmann, C.; Gerhart-Hines, Z.; Meziane, H.; Lerin, C.; Daussin, F.; Messadeq, N.; Milne, J.; Lambert, P.; Elliott, P.; et al. Resveratrol improves mitochondrial function and protects against metabolic disease by activating SIRT1 and PGC-1alpha. Cell 2006, 127, 1109-1122. [CrossRef] [PubMed]

109. Casanova, E.; Baselga-Escudero, L.; Ribas-Latre, A.; Arola-Arnal, A.; Bladé, C.; Arola, L.; Salvadó, M.J. Epigallocatechin gallate counteracts oxidative stress in docosahexaenoxic acid-treated myocytes. Biochim. Biophys. Acta Bioenerg. 2014, 1837, 783-791. [CrossRef] [PubMed]

110. Wang, L.; Wang, Z.; Yang, K.; Shu, G.; Wang, S.; Gao, P.; Zhu, X.; Xi, Q.; Zhang, Y.; Jiang, Q. Epigallocatechin Gallate Reduces Slow-Twitch Muscle Fiber Formation and Mitochondrial Biosynthesis in C2C12 Cells by Repressing AMPK Activity and PGC-1 $\alpha$ Expression. J. Agric. Food Chem. 2016, 64, 6517-6523. [CrossRef]

111. Wei, H.; Meng, Z. Protective effects of epigallocatechin-3-gallate against lead-induced oxidative damage. Hum. Exp. Toxicol. 2011, 30, 1521-1528. [CrossRef]

112. Deng, Y.-T.; Chang, T.-W.; Lee, M.-S.; Lin, J.-K. Suppression of free fatty acid-induced insulin resistance by phytopolyphenols in C2C12 mouse skeletal muscle cells. J. Agric. Food Chem. 2012, 60, 1059-1066. [CrossRef]

113. Babu, P.V.A.; Liu, D.; Gilbert, E.R. Recent advances in understanding the anti-diabetic actions of dietary flavonoids. J. Nutr. Biochem. 2013, 24, 1777-1789. [CrossRef]

114. Green, C.J.; Macrae, K.; Fogarty, S.; Hardie, D.G.; Sakamoto, K.; Hundal, H.S. Counter-modulation of fatty acid-induced pro-inflammatory nuclear factor kappaB signalling in rat skeletal muscle cells by AMP-activated protein kinase. Biochem. J. 2011, 435, 463-474. [CrossRef] [PubMed]

115. Dong, Z. Effects of food factors on signal transduction pathways. Biofactors 2000, 12, 17-28. [CrossRef] [PubMed]

116. Pournourmohammadi, S.; Grimaldi, M.; Stridh, M.H.; Lavallard, V.; Waagepetersen, H.S.; Wollheim, C.B.; Maechler, P. Epigallocatechin-3-gallate (EGCG) activates AMPK through the inhibition of glutamate dehydrogenase in muscle and pancreatic B-cells: A potential beneficial effect in the pre-diabetic state? Int. J. Biochem. Cell Biol. 2017, 88, 220-225. [CrossRef] [PubMed]

117. Zhang, Z.F.; Li, Q.; Liang, J.; Dai, X.Q.; Ding, Y.; Wang, J.B.; Li, Y. Epigallocatechin-3-O-gallate (EGCG) protects the insulin sensitivity in rat L6 muscle cells exposed to dexamethasone condition. Phytomedicine 2010, 17, 14-18. [CrossRef] [PubMed]

118. Sheena, A.; Mohan, S.S.; Haridas, N.P.A.; Anilkumar, G. Elucidation of the Glucose Transport Pathway in Glucose Transporter 4 via Steered Molecular Dynamics Simulations. PLoS ONE 2011, 6, e25747. [CrossRef]

119. Jung, K.H.; Choi, H.S.; Kim, D.H.; Han, M.Y.; Chang, U.J.; Yim, S.-V.; Song, B.C.; Kim, C.-H.; Kang, S.A. Epigallocatechin gallate stimulates glucose uptake through the phosphatidylinositol 3-kinase-mediated pathway in L6 rat skeletal muscle cells. J. Med. Food 2008, 11, 429-434. [CrossRef] 
120. Kong, A.-N.T.; Owuor, E.; Yu, R.; Hebbar, V.; Chen, C.; Hu, R.; Mandlekar, S. Induction of xenobiotic enzymes by the map kinase pathway and the antioxidant or electrophile response element (ARE/EpRE), ${ }^{+, \neq}$. Drug Metab. Rev. 2001, 33, 255-271. [CrossRef]

121. Lee, W.J.; Shim, J.-Y.; Zhu, B.T. Mechanisms for the Inhibition of DNA Methyltransferases by Tea Catechins and Bioflavonoids. Mol. Pharmacol. 2005, 68, 1018-1030. [CrossRef]

122. Choi, K.-C.; Jung, M.G.; Lee, Y.-H.; Yoon, J.C.; Kwon, S.H.; Kang, H.-B.; Kim, M.-J.; Cha, J.-H.; Kim, Y.J.; Jun, W.J.; et al. Epigallocatechin-3-gallate, a histone acetyltransferase inhibitor, inhibits EBV-induced B lymphocyte transformation via suppression of RelA acetylation. Cancer Res. 2009, 69, 583-592. [CrossRef]

123. Granja, A.; Frias, I.; Neves, A.R.; Pinheiro, M.; Reis, S. Therapeutic Potential of Epigallocatechin Gallate Nanodelivery Systems. Biomed. Res. Int. 2017, 2017. [CrossRef]

124. Liu, R.H. Potential Synergy of Phytochemicals in Cancer Prevention: Mechanism of Action. J. Nutr. 2004, 134, 3479S-3485S. [CrossRef] [PubMed]

125. de Kok, T.M.; van Breda, S.G.; Manson, M.M. Mechanisms of combined action of different chemopreventive dietary compounds. Eur. J. Nutr. 2008, 47, 51-59. [CrossRef] [PubMed]

126. Rondanelli, M.; Opizzi, A.; Perna, S.; Faliva, M.; Solerte, S.B.; Fioravanti, M.; Klersy, C.; Edda, C.; Maddalena, P.; Luciano, S.; et al. Improvement in insulin resistance and favourable changes in plasma inflammatory adipokines after weight loss associated with two months' consumption of a combination of bioactive food ingredients in overweight subjects. Endocrine 2013, 44, 391-401. [CrossRef]

127. Belza, A.; Frandsen, E.; Kondrup, J. Body fat loss achieved by stimulation of thermogenesis by a combination of bioactive food ingredients: A placebo-controlled, double-blind 8-week intervention in obese subjects. Int. J. Obes. 2007, 31, 121-130. [CrossRef] [PubMed]

(C) 2019 by the authors. Licensee MDPI, Basel, Switzerland. This article is an open access article distributed under the terms and conditions of the Creative Commons Attribution (CC BY) license (http://creativecommons.org/licenses/by/4.0/). 